\title{
HUBUNGAN ANTARA HIPERTENSI DENGAN PREMENSTRUAL SYNDROME PADA WANITA USIA REPRODUKTIF
}

\author{
Azhim Rahmawati ${ }^{1}$, Retno Siryaningsih ${ }^{2}$, Safari Wahyu Jatmiko ${ }^{1}$ \\ ${ }^{1}$ Fakultas Kedokteran Unoversitas Muhammadiyah Surakarta \\ ${ }^{2}$ RS PKU Muhammadiyah Surakarta
}

\begin{abstract}
Premenstrual syndrome (PMS) is a cycle disorder which is commonly occured during the luteal phase of the menstrual cycle and will dissapear at the time of menstruation. Ninety percent of women on reproductive ages experience symptomps of PMS and 10\% of them experience severe premenstrual symptomps that cuse physical disturbance, medical care necessity, even worst death. Hypertension is a risk factor for a PMS. The aim of this research is to find out a conection between PMS and hypertension. This research was designated using analytic observational with cross sectional approach. We used purposive sampling to get sample. Based on sample formula, we got 104 respondents which is consist of 52 women with hypertension and 52 women normotensive. To obtain data, we used shortened premenstrual syndrome assesment form (SPAF). Data collected were analyzed by chi square test. The result showed that the value of $p=0.00(p<0.005)$. This result indicated that there is a conection between hypertension and PMS occurence in reproductive age. The probability of hypertension women to get PMS is 6.75 .
\end{abstract}

Keywords: Hypertension, Premenstrual Syndrome, reproductive age

\section{PENDAHULUAN}

PMS merupakan gangguan siklus yang umumnya terjadi selama fase luteal pada siklus menstruasi dan akan menghilang pada saat menstruasi (Biggs dan Demuth, 2011). Gejala yang timbul pada PMS misalnya perut kembung, sakit kepala, depresi, kecemasan, insomnia, lelah, dan mudah tersinggung (Hillegas, 2007).

Sebanyak $90 \%$ wanita pada usia reproduktif mengalami gejala PMS. Wanita pada usia dekade empat paling sering mengalami PMS (Moreno, 2012). Menurut WHO, usia reproduktif 15-44 tahun tetapi dikatakan usia wanita dewasa adalah 20-59 tahun (WHO, 2013).

Perkiraan insiden gejala PMS berkisar antara $25-100 \%$ pada perempuan menstruasi. Kebanyakan gejala tidak berat, namun 10\% wanita mengalami gejala PMS yang berat dan memerlukan perawatan medis (Hillegas, 2007).

Hipertensi merupakan masalah kesehatan serius yang terjadi di seluruh dunia. Menurut data Riset Kesehatan Dasar tahun 2013 prevalensi hipertensi di Indonesia adalah 25,8\% dari jumlah penduduk.
Pada pasien hipertensi terjadi peningkatan aktifitas saraf simpatis yang mengakibatkan peningkatan sekresi katekolamin. Sementara itu pada pasien hipertensi terjadi juga peningkatan jalur aktifitas hormon Renin-angiotensinaldosteron. Hal ini menyebabkan terjadinya peningkatan kadar estrogen (Babyminakshi et $a l$, 2006). Ketidakseimbangan antara estrogen dengan progesteron merupakan salah satu faktor terjadinya PMS (Hillegas, 2007).

Berdasarkan latar belakang ini, penulis bermaksud meneliti tentang hubungan hipertensi dengan PMS.

\section{METODE PENELITIAN}

Penelitian ini merupakan penelitian analitik observasional menggunakan pendekatan cross sectional. Data diambil dari sampel yang dipilih secara purposive sampling.

Penelitian dilakukan pada bulan Desember 2014. Pada saat penelitian didapatkan 170 responden. Dari 170 responden tersebut ditemukan 104 responden yang memenuhi kriteria inklusi. Responden dibedakan menjadi dua kelompok, 
yakni kelompok yang hipertensi sebanyak 52 responden dan kelompok yang tidak hipertensi sebanyak 52 responden.
Responden diminta untuk mengisi kuesioner (SPAF). Data yang didapatkan diolah dengan menggunakan uji Chi square test.

\section{HASIL DAN PEMBAHASAN}

\begin{tabular}{|c|c|c|c|c|c|c|c|}
\hline & PMS & $\%$ & Non PMS & $\%$ & total & x & P \\
\hline Hipertensi & 39 & 70,9 & 13 & 26,53 & 52 & 20,41 & 0,00 \\
\hline Tidak Hipertensi & 16 & 29,09 & 36 & 73,47 & 52 & & \\
\hline Jumlah & 55 & 100 & 49 & 100 & 104 & & \\
\hline
\end{tabular}

Dari tabel di atas diperoleh hasil uji statistik menggunakan chi square test dan didapatkan nilai $\mathrm{p}=0,00(<0,05)$ sehingga dapat disimpulkan ada hubungan antara hipertensi dengan PMS. Hasil analisis dengan menggunakan odd rasio diperoleh nilai 6,75 yang berarti pada pasien hipertensi berisiko terkena PMS 6,75 kali dari pada orang yang tidak memiliki riwayat hipertensi.

Hipertensi dapat menyebabkan PMS karena pada hipertensi terjadi peningkatan aktifitas saraf simpatik yang mengakibatkan sekresi katekolamin meningkat dan menyebabkan kenaikan kadar estrogen (Babyminaskhi, 2006). Peningkatan katekolamin menyebabkan peningkatan sekresi GnRH pada hipotalamus. GnRH (Gonadotropine Releasing Hormone) yang terbentuk menyebabkan dilepaskannya FSH (Folicle Stimulating Hormon). FSH merangsang folikel pada ovarium untuk matang. Akibat dari perangsangan ini adalah dibentuknya estrogen sehingga kadar estrogen meningkat sedangkan kadar progesteron tidak berubah. Ketidakseimbangan antara etsrogen dengan progesteron menyebabkan terjadinya PMS (Hillegas, 2007).

\section{SIMPULAN}

Terdapat hubungan antara hipertensi dengan PMS pada wanita usia reproduktif.

\section{DAFTAR PUSTAKA}

Babyminashi, LP., Manggala, K., Afroz, S., Nanda, S., Sudhir, P., 2006, Effect of Premenstrual Stress on Cardiovascular System and Central Nervous System, J Obst Gynecol, 56:156-8

Biggs, W., Demuth, R., 2011, Premenstrual Syndrome and Premenstrual Dysphoric Disorder, $J \mathrm{Am}$ Acad Fam Pshic, 84:929

Hillegas, K., B., 2007, Gangguan Sistem Reproduksi Wanita, dalam: Price, SP., Wilson, L (eds), Patofisiologi Konsep Klinis dan Prosesproses Penyakit, edisi 6, Jakarta:EGC

Moreno, MA., 2012, Premenstrual syndrome, Http:// emedicine.medscape.com/article/241381overview, (10 oktober 2014)

Badan Penelitian dan Pengembangan Kesehatan, 2013, Riset Kesehatan Dasar, Jakarta:, Kementrian Kesehatan RI

World Health Organization. 2013, A Global Brief on Hypertension, http://www.who.int/ cardiovascular_disease/publication/global_ brief_hypertension/en/, (3 oktober 2014) 